Commentaries on judicial decisions $\frac{\text { Studia luridica Lublinensia vol. XXX, 5, } 2021}{\text { DOI: 10.17951/sil.2021.30.5.643-654 }}$

\title{
Jacek Kosonoga
}

Lazarski University in Warsaw, Poland

ORCID: 0000-0001-7348-944X

jacek.kosonoga@lazarski.pl

\section{Postępowanie w przedmiocie wytknięcia właściwemu sądowi oczywistej obrazy przepisów. Glosa do postanowienia Sądu Najwyższego z dnia 28 sierpnia 2019 r. (II KO 56/19, OSNKW 2019, nr 10, poz. 58)}

Proceedings with Respect to Reproach for a Flagrant Violation of the Law by a Competent Court: Commentary on the Decision of the Supreme Court of 28 August 2019 (II KO 56/19, OSNKW 2019, no. 10 , item 58)

\begin{abstract}
ABSTRAKT
W analizowanym orzeczeniu Sąd Najwyższy wyraził pogląd, iż odwołanie od postanowienia wytykającego właściwemu sądowi stwierdzoną przy rozpoznawaniu sprawy karnej oczywistą obrazę przepisów (art. 40 § 2a i 2 b ustawy Prawo o ustroju sądów powszechnych) podlega rozpoznaniu przez Sąd Najwyższy w Izbie Karnej przy zastosowaniu regulacji prawnych Kodeksu postępowania karnego o zażaleniu. Rozpoczęcie procedury określonej w art. 40 § 1 ustawy Prawo o ustroju sądów powszechnych objęte jest cezurą czasową, wyznaczoną datą orzekania w przedmiocie środka odwoławczego, a jej zakończenie powinno nastąpić niezwłocznie po wpłynięciu wyjaśnień lub upływie terminu do ich złożenia przez wydanie postanowienia w przedmiocie wytknięcia uchybienia. Sąd odwoławczy wydaje orzeczenie zarówno wtedy, gdy dochodzi do wytknięcia uchybienia, jak i wówczas, gdy $\mathrm{z}$ tego rezygnuje. W glosie zaaprobowano powyższe tezy, rozwijając argumentację na ich poparcie. Skrytykowano natomiast pogląd przeciwny, opierający się na twierdzeniu, że zainicjowanie procedury wytknięcia uchybienia dopuszczalne jest także po wydaniu orzeczenia kończącego sprawę. Dokonując systemowej analizy problematyki wytyku jurysdykcyjnego, zgłoszono postulat ujednolicenia
\end{abstract}

CORRESPONDENCE ADDRESS: Jacek Kosonoga, University Professor, PhD, Dr Habil., Lazarski University (Warszawa), Faculty of Law and Administration, Department of Criminal Law, ul. Świeradowska 43, 02-662 Warszawa, Poland. 
art. 97 § 1 ustawy o Sądzie Najwyższym z art. 40 § 2a ustawy Prawo o ustroju sądów powszechnych i wprowadzenia - w ramach instancji poziomej - odwołania od orzeczenia Sądu Najwyższego.

Słowa kluczowe: środek odwoławczy; cezura czasowa; wytknięcie właściwemu sądowi oczywistej obrazy przepisów; wytknięcie uchybienia; odwołanie

W analizowanym orzeczeniu Sąd Najwyższy odniósł się do instytucji tzw. wytyku judykacyjnego, zwanego również sądowym lub orzeczniczym. Istota tej instytucji została określona w art. 40 § 1 ustawy Prawo o ustroju sądów powszechnych, ${ }^{1}$ zgodnie z którym sąd apelacyjny lub sąd okręgowy, jako sąd odwoławczy, w razie stwierdzenia przy rozpoznawaniu sprawy oczywistej obrazy przepisów, niezależnie od innych uprawnień, wytyka uchybienie właściwemu sądowi. ${ }^{2}$

Charakter prawny wytyku orzeczniczego nie jest w doktrynie rozumiany jednoznacznie. $Z$ jednej strony twierdzi się, że w przepisie tym mowa jest o nadzorze judykacyjnym, w odróżnieniu od nadzoru służbowego i administracyjnego, ${ }^{3} \mathrm{z}$ drugiej zaś, że nie jest to czynność procesowa, lecz czynność służbowa, skierowana pod adresem danego sędziego lub sędziów, a skutki wytknięcia mają charakter poniekąd dyscyplinarny. ${ }^{4}$ Przyjmuje się również, że instytucja ta pełni przede wszystkim funkcję prewencyjną, ponieważ jej celem nie jest naprawienie wadliwości występującej w danym postępowaniu, lecz zapobieżenie takim wadliwościom w przyszłości. Wykazuje ona także cechy quasi-dyscyplinarne, gdyż wytknięcie dotyczy nie tyle sądu rozumianego jako sąd procesowy, ile konkretnego składu orzekającego, konkretnych sędziów. ${ }^{5}$ Zauważa się też, że nadzór sprawowany w tym trybie nie ma charakteru procesowego, wykonywany jest poza tokiem instancji, wyłącznie w interesie wymiaru sprawiedliwości, a nie w interesie indywidualnym

1 Ustawa z dnia 27 lipca 2001 r. - Prawo o ustroju sądów powszechnych (Dz.U. 2019, poz. 52), dalej: u.s.p.

2 Od tzw. wytyku orzeczniczego należy odróżnić instytucję zwrócenia uwagi na piśmie (wytyk administracyjny), o której mowa w art. 37 § 4 u.s.p.

3 B. Godlewska-Michalak [w:] Prawo o ustroju sąów powszechnych, red. A. Górski, Warszawa 2012, s. 168; H. Kempisty, Ustrój sądów. Komentarz, Warszawa 1966, s. 120. Odmiennie Z. Resich, Nauka o organach ochrony prawnej, Warszawa 1973, s. 37.

4 S. Włodyka, Nadzór nad orzecznictwem sądowym w sprawach cywilnych $w$ świetle zasady niezawistości sędziowskiej, [w:] Rozprawy prawnicze. Księga pamiatkowa dla uczczenia pracy naukowej Kazimierza Przybyłowskiego, red. W. Osuchowski, M. Sośniak, B. Walaszek, Kraków-Warszawa 1964, s. 485; idem, Organizacja wymiaru sprawiedliwości PRL, Warszawa 1963, s. 66.

5 Idem, Funkcje Sądu Najwyższego, Kraków 1965, s. 67; T. Ereciński, J. Gudowski, J. Iwulski, [w:] Prawo o ustroju sądów. Ustawa o Krajowej Radzie Sadownictwa. Komentarz, red. J. Gudowski, Warszawa 2009, s. 138; K. Piasecki, Organizacja wymiaru sprawiedliwości w Polsce, Warszawa 1995, s. 159. 
stron, ${ }^{6}$ stanowi więc formę pozainstancyjnego wytknięcia sądowi niższej instancji nieprawidłowości popełnionych w postępowaniu przy rozpoznawaniu sprawy. ${ }^{7}$

Jak wynika z powyższego, brak jest zgodności chociażby co do tego, czy wytknięcie oczywistej obrazy przepisów jest czynnością z zakresu nadzoru judykacyjnego czy też z zakresu nadzoru administracyjnego. Wprawdzie z ustawowego usytuowania art. 40 u.s.p. wynika, że ustawodawca łączy go z nadzorem administracyjnym, o czym świadczy wyraźnie intytulacja rozdziału $5,{ }^{8}$ a czynności związane z wytknięciem uchybienia podejmowane są z urzędu. Brak jest jednak typowej dla nadzoru administracyjnego podległości służbowej. Dodatkowo reakcja na oczywistą obrazę przepisów ograniczona jest jedynie do wytknięcia uchybienia i nie polega na władczym ingerowaniu w działalność podmiotu nadzorowanego. Co więcej, zadania z zakresu nadzoru administracyjnego koncentrują się głównie na działalności aparatu administracyjnego, podczas gdy wytknięcie dotyczy naruszenia przepisów w związku z rozpoznawaniem sprawy i tym samym pośrednio odnosi się do sfery orzekania. Słusznie też zauważa się w doktrynie, że istotne znaczenie ma podmiot, któremu powierzono obowiązek nadzoru, jego usytuowanie wśród innych organów oraz gwarancje niezawisłości i mocne związanie realizacji wytknięcia z trybem procesowym przewidzianym dla działalności jurysdykcyjnej. ${ }^{9}$ Przesądza to, że omawiany środek, jakkolwiek cechuje się swoistym charakterem prawnym, stanowiącym wypadkową elementów nadzoru zarówno judykacyjnego, jak i administracyjnego, wykazuje zdecydowanie większe powinowactwo z tym pierwszym.

Tym samym wypada podzielić pogląd, że wytknięcie dokonane na podstawie art. 40 u.s.p. jest rozwiązaniem mieszanym, łączy bowiem cechy nadzoru judykacyjnego, gdyż jest kierowane do organu orzekającego w związku z naruszeniem przepisów prawa podczas wydawania orzeczenia przez ten organ, $\mathrm{z}$ cechami nadzoru administracyjnego nad działalnością sądów, gdyż konsekwencje wytyku dotykają bezpośrednio i osobiście sędziów, którzy zasiadali w składzie sądu. ${ }^{10}$

W analizowanym orzeczeniu Sąd Najwyższy przyjął, że odwołanie od postanowienia wytykającego właściwemu sądowi stwierdzoną przy rozpoznawaniu sprawy karnej oczywistą obrazę przepisów (art. $40 \S 2 \mathrm{a}$ i $2 \mathrm{~b}$ u.s.p.) podlega rozpoznaniu

6 H. Kempisty, op. cit., s. 119-120.

7 Z. Resich, op. cit., s. 37-38.

8 Nie bez racji podnosi się wątpliwość, czy art. 40 u.s.p. powinien być zamieszczony w rozdziale dotyczącym nadzoru nad działalnością administracyjną sądów, gdyż w istocie dotyczy on kwestii stosowania lub wykładni prawa. Ponadto, co istotne, wyciągnięcie konsekwencji wobec sądu niższej instancji należy do organu nadzoru służbowego, natomiast rola sądu odwoławczego ogranicza się do samej sygnalizacji. Zob. T. Ereciński, J. Gudowski, J. Iwulski, op. cit., s. 138.

9 A. Bąk, Wytknięcie obrazy przepisu w sprawie cywilnej, „Przegląd Sądowy” 2002, nr 7-8, s. $137-138$.

${ }^{10}$ Wyrok TK z dnia 15 stycznia 2009 r., K 45/07, OTK-A 2009, nr 1, poz. 3; T. Ereciński, J. Gudowski, J. Iwulski, op. cit., s. 138; J. Kosonoga, System środków dyscyplinujacych uczestników postępowania karnego, Warszawa 2014. 
przez Sąd Najwyższy w Izbie Karnej przy zastosowaniu regulacji prawnych Kodeksu postępowania karnego o zażaleniu. Rozpoczęcie procedury określonej w art. $40 \S 1$ u.s.p. objęte jest cezurą czasową, wyznaczoną datą orzekania w przedmiocie środka odwoławczego, a jej zakończenie powinno nastąpić niezwłocznie po wpłynięciu wyjaśnień lub upływie terminu do ich złożenia przez wydanie postanowienia w przedmiocie wytknięcia uchybienia. Sąd odwoławczy wydaje orzeczenie zarówno wtedy, gdy dochodzi do wytknięcia uchybienia, jak i wówczas, gdy z tego rezygnuje.

Są to tezy trafne i zasadniczo zbieżne $\mathrm{z}$ dotychczasową linią orzeczniczą innych izb Sądu Najwyższego. Warto przy tym jednak zwrócić uwagę na swoistą ewolucję, jaką przeszły przepisy dotyczące wytyku judykacyjnego, tym bardziej że - jak się wydaje - nie jest to kwestia ostatecznie zamknięta, skoro przy okazji niniejszego orzeczenia Sąd Najwyższy wprost wyraził postulat de lege ferenda związany z usprawnieniem postępowania odwoławczego związanego z wytykiem. Pewne wątpliwości dotyczą również porównania ustawy Prawo o ustroju sądów powszechnych oraz ustawy o Sądzie Najwyższym w kontekście przebiegu postępowania w przedmiocie wytknięcia uchybienia.

Szczególnie istotną kwestią, związaną z wytknięciem oczywistej obrazy przepisów, jest problematyka gwarancji proceduralnych przysługujących sędziom, do których jest on adresowany. Zagadnienie to budziło zasadnicze wątpliwości w poprzednim stanie prawnym, w którym sąd apelacyjny lub sąd okręgowy przed wytknięciem uchybienia mógł jedynie żądać wyjaśnień od sędziego przewodniczącego składowi sądu orzekającego w pierwszej instancji, co oznaczało, że złożenie wyjaśnień było możliwe wyłącznie wtedy, gdy taką wolę wyraził sąd odwoławczy. Po nowelizacji z dnia 18 sierpnia 2011 r., ${ }^{11}$ która była następstwem wyroku Trybunału Konstytucyjnego, ${ }^{12}$ uprawnienia te są znacznie większe. Zgodnie bowiem z treścią art. $40 \S 1$ zdanie drugie u.s.p. przed wytknięciem uchybienia poucza się sędziego, asesora sądowego wchodzących w skład sądu orzekającego w pierwszej instancji o możliwości złożenia na piśmie wyjaśnień w terminie siedmiu dni. Jest to uprzedni w stosunku do ewentualnego wytknięcia obowiązek sądu apelacyjnego lub sądu okręgowego orzekającego jako sąd odwoławczy. W efekcie więc złożenie

${ }^{11}$ Ustawa z dnia 18 sierpnia 2011 r. o zmianie ustawy - Prawo o ustroju sądów powszechnych oraz niektórych innych ustaw (Dz.U. 2011, nr 203, poz. 1192).

12 Wyrok TK z dnia 15 stycznia 2009 r., K 45/07, OTK-A 2009, nr 1, poz. 3 . W uzasadnieniu wyroku podnoszono między innymi, że ustawodawca pominął w postępowaniu w przedmiocie wytknięcia zasadę audiatur et altera pars. Skoro następstwa wytyku odnoszą się do konkretnych praw i mają materialne konsekwencje, otwarcie określonej drogi wyjaśniającej dla członków składu uznano za konieczność. Trybunał zakwestionował brak możliwości ustosunkowania się do wytyku przez sędziów zasiadających w składzie sądu, do którego jest on skierowany. Gwarancji takiej w ocenie Trybunału nie dawała sama możliwość żądania wyjaśnień od składu orzekającego, jako środek fakultatywny i stosowany przez sąd dokonujący wytknięcia, według jego uznania. W konsekwencji Trybunał orzekł o niezgodności kwestionowanej regulacji z zasadami demokratycznego państwa prawnego wyrażonymi w art. 2 Konstytucji RP oraz stwierdził naruszenie zasady prawidłowej legislacji. 
wyjaśnień nie zależy już wyłącznie od woli sądu, który rozważa zastosowanie wytknięcia, lecz od sądu, którego wytknięcie ma dotyczyć. Tym samym stworzono realne gwarancje ustosunkowania się do ewentualnych uchybień stanowiących obrazę przepisów prawa. Niemniej istotnym wzmocnieniem gwarancji procesowych przysługujących składowi orzekającemu, do którego adresowany jest wytyk, było wprowadzenie zaskarżalności orzeczeń w przedmiocie wytyku, co nastąpiło na skutek dodania art. 40 § 2a u.s.p. ${ }^{13}$ Rozwiało to wszelkie wątpliwości co do dopuszczalności zaskarżania postanowień w przedmiocie wytknięcia oczywistej obrazy przepisów. W poprzednim stanie prawnym zasadnie podnoszono, że poza ewentualnym złożeniem wyjaśnień brak było możliwości kwestionowania zarzutów stanowiących przedmiot wytknięcia. W szczególności na postanowienie zawierające wytknięcie nie przysługiwało zażalenie. ${ }^{14}$ Uprawnień do zaskarżania tego rodzaju postanowień nie sposób było również domniemywać ${ }^{15}$ ani wywodzić z Kodeksu postępowania karnego ${ }^{16}$ czy też z Kodeksu postępowania cywilnego. ${ }^{17}$

Możliwość wytknięcia oczywistej obrazy przepisów przewidziano także w ustawie o Sądzie Najwyższym. Również w tym przypadku regulacje prawne przeszły

${ }^{13}$ Zob. art. 1 pkt 17 lit. a ustawy z dnia 12 lipca 2017 r. o zmianie ustawy - Prawo o ustroju sądów powszechnych oraz niektórych innych ustaw (Dz.U. 2017, poz. 1452). W motywach ustawodawczych wskazywano, że dokonując oceny odwołania, Sąd Najwyższy będzie uprawniony do utrzymania w mocy postanowienia zawierającego wytknięcie uchybienia bądź do jego uchylenia, kończącego rozpoznawanie sprawy w tym zakresie, w całości lub w części. Powyższe pozwoli na zapewnienie kontroli zasadności udzielonego „wytyku”, w tym w zakresie oceny, czy rzeczywiście doszło do obrazy przepisów noszącej znamiona oczywistości. Ponadto orzecznictwo Sądu Najwyższego w tym zakresie pozwoli na wypracowanie jednolitych kryteriów orzekania przez sądy odwoławcze niniejszej instytucji, co wpłynie na generalną poprawę jakości orzecznictwa sądów. Zob. Poselski projekt ustawy o zmianie ustawy - Prawo o ustroju sądów powszechnych oraz niektórych innych ustaw. Sejm RP VIII kadencji, druk nr 1491.

${ }_{14}$ Postanowienie SN z dnia 21 lipca 2011 r., V CZ 35/11, Legalis nr 537541; postanowienie SN z dnia 17 marca 2005 r., SNO 7/05, OSNSD 2005, nr 1, poz. 35.

15 Postanowienie SN z dnia 24 kwietnia 2012 r., VI KZ 1/12, Legalis nr 492127. Por. również postanowienie SN z dnia 27 stycznia 2010 r. (WZ 56/09, OSNKW 2010, nr 7, poz. 60, z glosą M. Siwka, LEX/el. 2010), w którym przyjęto swoiste rozwiązanie przejściowe i stwierdzono, że skoro art. $40 \S 1$ u.s.p. uznany został za niezgodny z art. 2 Konstytucji RP, to należy przyjąć, że - do czasu uregulowania przez ustawodawcę formy i trybu postępowania umożliwiającego sędziemu realizację jego prawa do złożenia wyjaśnień - w sprawach karnych powinno się stosować posiłkowo, w drodze analogii, przepisy o postępowaniu zażaleniowym zawarte w Kodeksie postępowania karnego. Pogląd ten trafnie zakwestionowano w postanowieniu SN z dnia 3 lutego 2011 r., V KK 229/10, OSNKW 2011, nr 2, poz. 19), a także w doktrynie, krytykując prawotwórczy charakter orzeczenia (M. Siwek, op. cit., teza 12).

16 Postanowienie SN z dnia 3 lutego 2011 r., V KK 229/10, OSNKW 2011, nr 2, poz. 19.

17 Postanowienie SN z dnia 21 lipca 2011 r., V CZ 35/11, Legalis nr 537541, z glosą J. Bodio, Postepowanie zwiazane z wydaniem wytyku w trybie art. 40 \$ 1 p.u.s.p. Glosa do postanowienia SN z dnia 21 lipca 2011 r., V CZ 35/11, „Gdańskie Studia Prawnicze. Przegląd Orzecznictwa” 2012, nr 3, s. 49 i n.; postanowienie SN z dnia 9 października 2009 r., I CNP 59/09, LEX nr 599736. 
pewnego rodzaju ewolucję. Początkowo w ustawie z dnia 23 listopada 2002 r. o Sądzie Najwyższym ${ }^{18}$ brak było obowiązku pouczenia o możliwości złożenia wyjaśnień w przypadku wytknięcia kierowanego przez Sąd Najwyższy (art. 65 $\S 1$ u.SN z 2002 r.). Organ ten mógł jedynie żądać stosownych wyjaśnień, a jeżeli $\mathrm{z}$ tego uprawnienia nie skorzystał, sędzia lub sędziowie wchodzący w skład sądu orzekającego pozbawieni byli możliwości zaprezentowania swojego stanowiska. Rozwiązanie to było krytykowane w doktrynie, ${ }^{19} \mathrm{w}$ konsekwencji ustawodawca zdecydował się na zmianę treści art. $65 \S 1$ u.SN z 2002 r. w ten sposób, że zobowiązał Sąd Najwyższy przed wytknięciem uchybienia do pouczenia sędziego lub sędziów wchodzących w skład sądu orzekającego o możliwości złożenia na piśmie wyjaśnień w terminie siedmiu dni. ${ }^{20}$ Przepis ten został powtórzony w obowiązującej ustawie z dnia 8 grudnia 2017 r. o Sądzie Najwyższym ${ }^{21}$ (art. 97 u.SN).

Zarówno poprzednia, jak i aktualna ustawa nie przewiduje jednak możliwości zaskarżania decyzji w przedmiocie wytyku. Trudno znaleźć przekonujące argumenty za tak istotnym zróżnicowaniem procedury związanej z wytknięciem uchybień na gruncie prawa o ustroju sądów powszechnych i ustawy o Sądzie Najwyższym. Są to tożsame rozwiązania prawne, powodujące analogiczne konsekwencje w sferze uprawnień sędziego, którego dotyczy wytknięcie, dlatego też w myśl zasady ubi eadem legis ratio, ibi eadem legis dispositio powinny być one analogicznie uregulowane. Uprawniony wydaje się zatem postulat de lege ferenda ujednolicenia art. $97 \S 1$ u.SN z art. 40 § 2a u.s.p. i wprowadzenia odwołania od orzeczenia Sądu Najwyższego w ramach instancji poziomej.

Na marginesie warto zwrócić uwagę, że zgodnie z art. 97 § 3 u.SN Sąd Najwyższy, w przypadku wytknięcia uchybienia, może zwrócić się z wnioskiem o rozpoznanie sprawy dyscyplinarnej do sądu dyscyplinarnego. Jest to jednak możliwe jedynie wówczas, gdy obraza przepisów jest nie tylko oczywista (art. $97 \S 1$ u.SN, art. $40 \S 1$ u.s.p.), ale jednocześnie rażąca (art. $107 \S 1$ pkt 1 u.s.p.). ${ }^{22}$ Odrębną kwestią, wychodzącą jednak poza zakres niniejszego opracowania, jest przy tym problematyka stosowania art. $93 \S 3$ u.SN w kontekście wyroku TSUE z dnia 15 lipca $2021 \mathrm{r}^{23}$

${ }^{18}$ Ustawa z dnia 23 listopada 2002 r. o Sądzie Najwyższym (t.j. Dz.U. 2016, poz. 1254 ze zm.), dalej: u.SN z 2002 r.

19 Zob. J. Kosonoga, Reproach for evident contempt of regulations in the criminal proceeding, „Ius Novum” 2014, nr 2, s. 125 i n.

${ }^{20}$ Ustawa z dnia 10 czerwca 2014 r. o zmianie ustawy o Sądzie Najwyższym (Dz.U. 2014, poz. 1031).

${ }^{21}$ Ustawa z dnia 8 grudnia 2017 r. o Sądzie Najwyższym (t.j. Dz.U. 2019, poz. 825 ze zm.), dalej: u.SN.

${ }^{22}$ Zob. np. wyrok SN z dnia 27 czerwca 2002 r., SNO 18/02, OSNSD 2002, nr 1-2, poz. 9; wyrok SN z dnia 2 czerwca 2006 r., SNO 24/06, OSNSD 2006, poz. 39.

${ }^{23}$ W sentencji wyroku Trybunału Sprawiedliwości z dnia 15 lipca 2021 r. w sprawie Komisja przeciwko Polsce (C-791/19) przyjęto, że Rzeczpospolita Polska uchybiła zobowiązaniom, które na 
Jak już wspomniano, rozpoznając analizowaną sprawę Sąd Najwyższy zasadnie przyjął, iż odwołanie od postanowienia wytykającego właściwemu sądowi stwierdzoną przy rozpoznawaniu sprawy karnej oczywistą obrazę przepisów (art. 40 § 2a i 2 b u.s.p.) podlega rozpoznaniu przez Sąd Najwyższy w Izbie Karnej przy zastosowaniu regulacji prawnych Kodeksu postępowania karnego o zażaleniu. Pogląd ten wpisuje się w stanowisko wypracowane już zarówno w Izbie Cywilnej, ${ }^{24}$ jak i w Izbie Pracy i Ubezpieczeń Społecznych..$^{25}$ Wprawdzie w art. 40 u.s.p. mowa jest o odwołaniu, lecz taka formuła redakcyjna nie zmienia ogólnej zasady zaskarżalności postanowień $\mathrm{w}$ drodze zażalenia. W orzecznictwie zasadnie zauważa się, że skoro zasadą jest wnoszenie środka odwoławczego za pośrednictwem organu wydającego zaskarżone orzeczenie, i to nie tylko w przypadku możliwości uwzględnienia tego środka przez organ wydający zaskarżone orzeczenie, to ewentualne odstępstwa od tej reguły powinny być uregulowane precyzyjnie i jednoznacznie. Stąd w razie regulacji otwartej - a taka ma miejsce na tle art. 40 § 2a u.s.p., gdyż nie rozstrzyga omawianego zagadnienia gramatycznie - należy w oparciu o dokonaną wykładnię systemową zaaprobować, charakterystyczne dla zażalenia, rozwiązanie polegające na wnoszeniu odwołania za pośrednictwem sądu (organu) wydającego zaskarżone orzeczenie. ${ }^{26}$

Szczególnie istotna jest jednak ta wypowiedź Sądu Najwyższego, która odnosi się do chronologii czynności składających się na procedurę wytyku judykacyjnego. Jak już wspomniano, Sąd Najwyższy stwierdził, iż rozpoczęcie procedury określonej $\mathrm{w}$ art. $40 \S 1$ u.s.p. objęte jest cezurą czasową, wyznaczoną datą orzekania w przedmiocie środka odwoławczego, a jej zakończenie powinno nastąpić niezwłocznie po wpłynięciu wyjaśnień lub upływie terminu do ich złożenia przez wydanie postanowienia w przedmiocie wytknięcia uchybienia. Jest to stanowisko słuszne, gdyż takie rozróżnienie początkowego i końcowego momentu procedury wytyku wynika wprost z kontekstu językowego art. $40 \S 1$ u.s.p. Przepis ten został zredagowany sekwencyjnie - sąd odwoławczy w pierwszej kolejności stwierdza bowiem oczywistą obrazę przepisów, a następnie wytyka uchybienie właściwemu sądowi, przy czym stwierdzenie powinno nastąpić przy rozpoznawaniu sprawy. Chodzi zatem o stwierdzenie uchybienia przy rozpoznawaniu sprawy, a nie po jej rozpoznaniu. Etap rozpoznawania sprawy kończy natomiast wydanie w jej przedmiocie orzeczenia merytorycznego; po

niej ciążą na mocy art. 19 ust. 1 akapit drugi Traktatu o Unii Europejskiej, m.in. „dopuszczając, aby w przypadku sędziów sądów powszechnych treść orzeczeń sądowych mogła być kwalifikowana jako przewinienie dyscyplinarne [art. $107 \S 1$ ustawy z dnia 27 lipca 2001 r. - Prawo o ustroju sądów powszechnych (Dz.U. $2001 \mathrm{nr} 98$ poz. 1070), w brzmieniu wynikającym z kolejnych zmian opublikowanych w Dzienniku Ustaw Rzeczypospolitej Polskiej z 2019 r. (poz. 52, 55, 60, 125, 1469 i 1495) oraz art. $97 \S \S 1$ i 3 ustawy z dnia 8 grudnia 2017 r. o Sądzie Najwyższym (Dz.U. 2018 poz. 5; tekst jednolity opublikowany w Dzienniku Ustaw Rzeczypospolitej Polskiej z 2019 r., poz. 825)]”.

${ }^{24}$ Postanowienie SN z dnia 5 lipca 2018 r., I CO 64/18, OSNC 2019, nr 2, poz. 23.

${ }_{25}$ Postanowienie SN z dnia 12 grudnia 2018 r., III PO 10/18, OSNP 2019, nr 1, poz. 104.

${ }^{26}$ Ibidem. 
tej czynności sąd niczego już nie rozpoznaje. Pojęcie rozpoznawania należy w tym przypadku odróżnić od kompleksu czynności składających się na wyrokowanie w rozumieniu rozdziału 47 Kodeksu postępowania karnego. Skoro zatem do stwierdzenia oczywistej obrazy przepisów ma dojść przy rozpoznawaniu sprawy, to nie może to mieć miejsca po wydaniu orzeczenia w przedmiocie środka odwoławczego. Redakcja art. $40 \S 1$ u.s.p. przypomina nieco formułę zastosowaną w art. $441 \S 1$ Kodeksu postępowania karnego, który możliwość zadania tzw. konkretnego pytania prawnego uzależnia od wyłonienia się ,przy rozpoznawaniu środka odwoławczego” zagadnienia prawnego wymagającego zasadniczej wykładni ustawy. Trudno wyobrazić sobie dopuszczalność rozpoznania pytania prawnego po wydaniu orzeczenia przez sąd odwoławczy. Z istoty rzeczy wytknięcie jest natomiast czynnością następczą w stosunku do stwierdzenia uchybienia. Nie są to czynności jednoczesne. Zachodzi pomiędzy nimi perspektywa czasowa, pozwalająca na ewentualne skorzystanie z możliwości złożenia wyjaśnień. Przed wytknięciem uchybienia poucza się bowiem sędziego, asesora sądowego wchodzących w skład sądu orzekającego w pierwszej instancji o możliwości złożenia na piśmie wyjaśnień w terminie siedmiu dni (art. 40 $\S 1$ u.s.p.). Oznacza to, że sąd odwoławczy najpierw, rozpoznając sprawę, stwierdza uchybienie, poucza o możliwości złożenia wyjaśnień, a następnie decyduje w przedmiocie wytknięcia. Stanowi to swoisty kompromis pomiędzy potrzebą zachowania sprawności postępowania odwoławczego i dotrzymaniem gwarancji procesowych sądu zagrożonego wytykiem.

Problematyka chronologii czynności składających się na wytknięcie uchybienia nie jest jednak rozumiana jednoznacznie. W orzecznictwie dopuszcza się bowiem zainicjowanie procedury wytknięcia uchybienia także po wydaniu orzeczenia kończącego sprawę. Podnosi się przy tym między innymi, że obowiązek pouczenia sędziego wchodzącego w skład sądu orzekającego w pierwszej instancji o możliwości złożenia na piśmie wyjaśnień w terminie siedmiu dni nie może tamować merytorycznego rozpoznania sprawy, gdyż nie ma wpływu na bieg tego postępowania i nie wpływa na jego wynik. Tym samym czynności sądu odwoławczego w kontekście wytknięcia uchybienia nie muszą wyprzedzać merytorycznego rozpoznania sprawy. Możliwe jest więc, że w toku narady nad wyrokiem sędzia sprawozdawca lub inny członek składu orzekającego zwraca uwagę na określoną wadę orzeczenia sądu pierwszej instancji. Jeżeli zostanie ona zaakceptowana przez skład sądu odwoławczego, to winna znaleźć swe odzwierciedlenie w pisemnych motywach wyroku sądu drugiej instancji, które po podpisaniu przez członków składu orzekającego stanowią impuls do kolejnych czynności. Chodzi o pouczenie sędziego wchodzącego w skład sądu orzekającego o możliwości złożenia wyjaśnień na piśmie. ${ }^{27}$

Powyższa koncepcja opiera się na następującej sekwencji czynności procesowych: wydanie orzeczenia kończącego sprawę, sporządzenie uzasadnienia ze 
wskazaniem „wady sądu pierwszej instancji, która daje impuls do pouczenia o możliwości złożenia wyjaśnień", następnie pouczenie sędziego o możliwości złożenia wyjaśnień na piśmie oraz finalnie wydanie postanowienia w przedmiocie wytyku. Propozycja ta skłania do polemiki. Rację ma Sąd Najwyższy orzekający w analizowanej sprawie, gdy zwraca uwagę, iż charakter postępowania uruchamianego na podstawie art. $40 \S 1$ u.s.p. niewątpliwie dowodzi, że jest ono działaniem „opresyjnym", wywołanym w ramach postępowania quasi-dyscyplinarnego ${ }^{28}$ pociągającym za sobą szereg dotkliwych skutków wobec członków składu sądu. Dlatego też wykładnia art. $40 \S 1$ u.s.p. musi zdecydowanie iść w kierunku progwarancyjnym dla ewentualnych podmiotów dotkniętych opisywaną procedurą. W tej sytuacji nie można przyjąć, iż stosowanie wytyku nie powinno być ograniczone czasowo, skoro nawet w postępowaniu stricte dyscyplinarnym występuje unormowanie określające cezurę czasową co do jego wszczęcia (art. $108 \S 1$ u.s.p.). Ponadto - jak zasadnie stwierdza Sąd Najwyższy - nie istnieją żadne racjonalne przesłanki do uznania, iż postępowanie „wytykowe” mogłoby być wszczęte w każdym czasie, niezależnie od rozpoznawania środka zaskarżenia przez sąd odwoławczy. Modelowo postanowienie w trybie art. $40 \S 1$ u.s.p. powinno być zatem wydane w tym samym dniu, co rozstrzygnięcie sądu okręgowego albo sądu apelacyjnego zapadłe w wyniku rozpoznania środka odwoławczego. Biorąc jednak pod uwagę potrzebę uwzględnienia procedury składania wyjaśnień przez sąd zagrożony wytknięciem, Sąd Najwyższy zasadnie dopuszcza koncepcję dwuetapowego postępowania w przedmiocie wytyku, przyjmując, że wezwanie do złożenia wyjaśnień powinno nastąpić do czasu wydania orzeczenia w przedmiocie środka odwoławczego, a wytknięcie powinno nastąpić niezwłocznie po wpłynięciu wyjaśnień lub upływie terminu do ich złożenia.

Można również argumentować, że skoro ustawowym wymogiem wytyku jest to, aby obraza przepisów była oczywista, czyli niebudząca wątpliwości, bezsporna, pewna, ${ }^{29}$ a przy tym oczywista dla każdego przeciętnego prawnika, ${ }^{30}$ to znaczy, że jest ona dostrzegalna już na samym początku rozpoznawania sprawy, najpóźniej zaś w momencie orzekania. Trudno zatem przyjąć, że jej stwierdzenie następuje dopiero np. w momencie szczegółowego uzasadniania orzeczenia sądu odwoławczego. Podważa to w pewnym sensie oczywistość takiego uchybienia. Wątpliwości budzi również twierdzenie, że każdorazowo uchybienie sądu pierwszej instancji mające stanowić oczywistą obrazę przepisów powinno najpierw zostać wskazane

${ }^{28}$ Zob. postanowienie SN z dnia 27 stycznia 2010 r., WZ 56/09, OSNKW 2010, nr 7, poz. 60; M. Radajewski, Wytknięcie uchybienia sądowi niższej instancji, „Przegląd Sądowy” 2018, nr 10, s. $60-73$.

${ }^{29}$ Uniwersalny słownik języka polskiego, red. S. Dubisz, t. 3, Warszawa 2003, s. 76.

${ }^{30}$ S. Włodyka, Funkcje..., s. 69; Z. Resich, op. cit., s. 38. Niektórzy autorzy przyjmują węższe kryterium - przeciętnego sędziego. Zob. np. A. Bąk, op. cit., s. 154. 
w uzasadnieniu orzeczenia kończącego postępowanie, a dopiero następnie spowodować skierowanie do sądu pouczenia o możliwości złożenia wyjaśnień. Oznacza to $\mathrm{w}$ istocie, że stwierdzenie oczywistej obrazy ma charakter uprzedni w stosunku do złożenia wyjaśnień i deprecjonuje te ostatnie. Sąd miałby wyjaśniać uchybienia, które i tak zostały już wskazane w uzasadnieniu. Powoduje to też pewną kolizję pomiędzy stwierdzeniem uchybienia w uzasadnieniu a ewentualnym uwzględnieniem odwołania, potwierdzającym, że do oczywistej obrazy przepisów nie doszło. Wprawdzie obraza przepisów, w szczególności wówczas, gdy miała wpływ na rozstrzygnięcie sądu odwoławczego, będzie wskazywana w uzasadnieniu, lecz motywy sądu odwoławczego nie powinny nosić cech sui generis wytyku.

W uzasadnieniu analizowanego orzeczenia Sąd Najwyższy zgłosił także postulat odstąpienia od wymogu składania wyjaśnień przez sąd zagrożony wytykiem w sytuacji dopuszczenia możliwości zaskarżenia postanowienia o wytknięciu uchybienia. W ocenie Sądu okoliczności prezentowane w wyjaśnieniach z reguły będą bowiem powtarzane w tym środku odwoławczym. Rezygnacja z obowiązku pouczania o możliwości składania wyjaśnień i uprawnienia do ich składania pozwoliłaby na realizowanie zaleceń Trybunału Konstytucyjnego ${ }^{31}$ bez obawy opóźnienia rozstrzygnięcia $\mathrm{w}$ sprawie głównej $\mathrm{i}$ wydawanie postanowienia $\mathrm{w}$ przedmiocie wytknięcia uchybienia w momencie kończenia postępowania odwoławczego.

Postulat Sądu Najwyższego jest z pewnością godny przemyślenia, w szczególności jeżeli uwzględni się, że na skutek kolejnych nowelizacji doszło do swoistego zdublowania gwarancji sądu zagrożonego wytykiem. Jak już wspomniano, początkowo sąd taki jedynie mógł zostać wezwany do złożenia wyjaśnień, jeżeli taką potrzebę stwierdził sąd odwoławczy. Nnastępnie został wyposażony w niezależne prawo złożenia wyjaśnień z obowiązkiem pouczenia go o tym, a w efekcie - dodatkowo wyposażony w możliwość złożenia zażalenia na postanowienie wytykające uchybienie. Tym samym adresat wytknięcia może zarówno składać wyjaśnienia, jak i skarżyć decyzję w tym przedmiocie. $Z$ jednej strony z pewnością rezygnacja z możliwości składania wyjaśnień by przyspieszyła postępowanie dotyczące wytknięcia i dała możliwość wydawania postanowienia już w momencie kończenia postępowania odwoławczego. Z drugiej strony jednak nie sposób nie dostrzegać klaryfikacyjnej roli wyjaśnień. Mogą one spowodować odstąpienie przez sąd odwoławczy od wydania postanowienia i zamknąć postępowanie w przedmiocie wytyku bez potrzeby wydawania decyzji procesowej stwierdzającej uchybienie oraz weryfikowania jej w drodze kontroli odwoławczej. Taka możliwość także przyczynia się do przyspieszenia postępowania.

Nie można natomiast podzielić argumentu, iż rezygnacja z wyjaśnień wpłynie na bieg postępowania głównego. Są to - czemu dał wyraz Sąd Najwyższy $\mathrm{w}$ analizowanym orzeczeniu - niezależne od siebie postępowania w tym sensie,

\footnotetext{
${ }^{31}$ Zob. przypis 13.
} 
że wydanie postanowienia co do wytyku nie opóźnia postępowania głównego, skoro z założenia może to nastąpić po jego zakończeniu. Wprawdzie możliwość złożenia zażalenia jest dalej idącym uprawnieniem niż samo złożenie wyjaśnień, lecz wydaje się, że dopiero suma tych uprawnień daje sądowi pełnię ochrony przed negatywnymi skutkami wytknięcia uchybienia.

\section{BIBLIOGRAFIA}

\section{Literatura}

Bąk A., Wytknięcie obrazy przepisu w sprawie cywilnej, „Przegląd Sądowy” 2002, nr 7-8.

Bodio J., Postępowanie związane z wydaniem wytyku w trybie art. 40 § 1 p.u.s.p. Glosa do postanowienia SN z dnia 21 lipca 2011 r., V CZ 35/11, „Gdańskie Studia Prawnicze. Przegląd Orzecznictwa" 2012, nr 3.

Ereciński T., Gudowski J., Iwulski J., [w:] Prawo o ustroju sąów. Ustawa o Krajowej Radzie Sadownictwa. Komentarz, red. J. Gudowski, Warszawa 2009.

Godlewska-Michalak B., [w:] Prawo o ustroju sądów powszechnych, red. A. Górski, Warszawa 2012.

Kempisty H., Ustrój sadów. Komentarz, Warszawa 1966.

Kosonoga J., Reproach for evident contempt of regulations in the criminal proceeding, „Ius Novum” 2014, nr 2.

Kosonoga J., System środków dyscyplinujacych uczestników postępowania karnego, Warszawa 2014.

Piasecki K., Organizacja wymiaru sprawiedliwości w Polsce, Warszawa 1995.

Radajewski M., Wytknięcie uchybienia sądowi niższej instancji, „Przegląd Sądowy” 2018, nr 10.

Resich Z., Nauka o organach ochrony prawnej, Warszawa 1973.

Siwek M., Glosa do postanowienia SN z dnia 27 stycznia 2010 r., WZ 56/09, LEX/el. 2010.

Uniwersalny słownik języka polskiego, red. S. Dubisz, t. 3, Warszawa 2003.

Włodyka S., Funkcje Sądu Najwyższego, Kraków 1965.

Włodyka S., Nadzór nad orzecznictwem sadowym $w$ sprawach cywilnych $w$ świetle zasady niezawistości sędziowskiej, [w:] Rozprawy prawnicze. Księga pamiattowa dla uczczenia pracy naukowej Kazimierza Przybyłowskiego, red. W. Osuchowski, M. Sośniak, B. Walaszek, Kraków-Warszawa 1964.

Włodyka S., Organizacja wymiaru sprawiedliwości PRL, Warszawa 1963.

\section{Inne}

Poselski projekt ustawy o zmianie ustawy - Prawo o ustroju sądów powszechnych oraz niektórych innych ustaw. Sejm RP VIII kadencji, druk nr 1491.

\section{Akty prawne}

Ustawa z dnia 27 lipca 2001 r. - Prawo o ustroju sądów powszechnych (Dz.U. 2019, poz. 52).

Ustawa z dnia 23 listopada 2002 r. o Sądzie Najwyższym (t.j. Dz.U. 2016, poz. 1254 ze zm.).

Ustawa z dnia 18 sierpnia 2011 r. o zmianie ustawy - Prawo o ustroju sądów powszechnych oraz niektórych innych ustaw (Dz.U. 2011, nr 203, poz. 1192).

Ustawa z dnia 10 czerwca 2014 r. o zmianie ustawy o Sądzie Najwyższym (Dz.U. 2014, poz. 1031). 
Ustawa z dnia 12 lipca 2017 r. o zmianie ustawy - Prawo o ustroju sądów powszechnych oraz niektórych innych ustaw (Dz.U. 2017, poz. 1452).

Ustawa z dnia 8 grudnia 2017 r. o Sądzie Najwyższym (t.j. Dz.U. 2019, poz. 825 ze zm.).

\section{Orzecznictwo}

Postanowienie SN z dnia 17 marca 2005 r., SNO 7/05, OSNSD 2005, nr 1, poz. 35. Postanowienie SN z dnia 9 października 2009 r., I CNP 59/09, LEX nr 599736.

Postanowienie SN z dnia 27 stycznia 2010 r., WZ 56/09, OSNKW 2010, nr 7, poz. 60.

Postanowienie SN z dnia 3 lutego 2011 r., V KK 229/10, OSNKW 2011, nr 2, poz. 19.

Postanowienie SN z dnia 21 lipca 2011 r., V CZ 35/11, Legalis nr 537541.

Postanowienie SN z dnia 24 kwietnia 2012 r., VI KZ 1/12, Legalis nr 492127.

Postanowienie SN z dnia 5 lipca 2018 r., I CO 64/18, OSNC 2019, nr 2, poz. 23.

Postanowienie SN z dnia 12 grudnia 2018 r., III PO 10/18, OSNP 2019, nr 1, poz. 104.

Postanowienie SN z dnia 28 sierpnia 2019 r., II KO 56/19, OSNKW 2019, nr 10, poz. 58.

Wyrok SN z dnia 27 czerwca 2002 r., SNO 18/02, OSNSD 2002, nr 1-2, poz. 9.

Wyrok SN z dnia 2 czerwca 2006 r., SNO 24/06, OSNSD 2006, poz. 39.

Wyrok TK z dnia 15 stycznia 2009 r., K 45/07, OTK-A 2009, nr 1, poz. 3.

\section{ABSTRACT}

In the commented judgement, the Supreme Court stated that an appeal against a decision reproaching a competent court for flagrant violation of the law while hearing a criminal case (Article $40 \S 2 \mathrm{a}$ and $2 \mathrm{~b}$ of the Law on the common court system) is heard by the Supreme Court in the Criminal Chamber in accordance with the provisions of the Code of Criminal Procedure on appeals. Commencement of the procedure laid down in Article $40 \S 1$ of the Law on the Common Court System is subject to the time limit set on the date of rendering a decision on an appeal, and its termination should take place immediately after the receipt of explanations or the expiry of the deadline for submitting them, in either case by issuing a decision on reproaching for a violation. The appellate court should issue its decision both when it finds the violation took place and when it resigns to do so. This commentary approves such an attitude, developing arguments to support it. On the other hand, the opposite view was criticized, based on the claim that initiation of the procedure for reproach for violation is also admissible after the final ruling has been issued. Having analysed the issue of reproach for violation of the law from the systemic point of view, the author postulates to unify Article $97 \S 1$ of the Act on the Supreme Court with Article $40 \S 2 \mathrm{a}$ of the Law on the Common Court System and to introduce an appeal against a ruling of the Supreme Court heard within so called horizontal instance.

Keywords: decision on an appeal; time limit; reproach for a flagrant violation of the law by a competent court; reproaching for a violation; an appeal 